\title{
Description of the Occurrence of Canine Dirofilariasis in the State of Rio de Janeiro, Brazil
}

\author{
Norma Labarthe ${ }^{+}$, Nádia Almosny, Jorge Guerrero*, \\ Ana Maria Duque-Araújo*
}

Faculdade de Veterinária, Centro de Ciências Médicas, Universidade Federal Fluminense, Rua Vital Brazil Filho 64, 24230-340 Niterói, RJ, Brasil * Merck \& Co., Inc., P.O. Box 2000, Rahway, NJ, 07065.0912, USA

In order to evaluate the prevalence of canine heartworm in the State of Rio de Janeiro, a multicenter survey was carried out in two phases. The survey involved 1376 dogs from two cities: Rio de Janeiro and Niterói, and its surroundings, including the eastern shore and mountain resorts, which were further divided into sections. In the first phase, 795 dog blood samples were examined by the modified Knott test for the detection of microfilariae. A total of 134 samples (16.85\%) were microfilaremic: $8.61 \%$ from Rio de Janeiro, 21.76\% from Niterói and its surroundings, 33.33\% from the eastern shore and $30.43 \%$ from the mountain resorts. In the second phase, 595 dog blood samples were examined first by the modified Knott test and the amicrofilaremic samples were subsequently examined by an immunoenzymatic test (ELISA) for antigen detection. In summary, 83 samples (13.95\%) were microfilaremic and 44 (7.98\%) of the amicrofilaremic samples were positive for heartworm antigen (occult infections). In Rio de Janeiro, $13.68 \%$ of the dogs were infected (i.e., antigen-and/or microfilaria-positive) and $8.51 \%$ of the dogs had microfilaremic infections. In comparison, Niterói and its surroundings showed values of $24.46 \%$ and $17.30 \%$ and the eastern shore showed values of $52.46 \%$ and $31.15 \%$. In contrast the mountain resorts showed $20 \%$ microfilaremic only.

Key words: Dirofilaria immitis - dirofilariasis - heartworm - canine

Dirofilaria immitis (Leidy 1856) is a parasitic nematode that is commonly found in the pulmonary arteries and right ventricle of canines; although dogs and wild canines are considered to be the natural hosts for this parasite, it can infect other species of animals, as well as man.

Since 1979, heartworms have been known as a zoonosis (OMS 1979). This filarial parasite needs mosquitoes as vectors, mostly those belonging to the genera Culex, Aedes or Anopheles. The distribution of the parasite is considered to be worldwide. Traditionally it is expected to be detected more frequently in coastal areas and in environments that sustain the development of these intermediate hosts (Genchi et al. 1988).

Diagnosis is generally made by concentration techniques that detect microfilariae in the blood. Lately, immunodiagnostic techniques have been developed which enable veterinarians to diagnose occult (amicrofilaremic) infections as well. This

\footnotetext{
${ }^{+}$Corresponding author. Fax: +55-21-295.2052. Graduate student in Parasitic Biology, Institute Oswaldo Cruz - FIOCRUZ

Received 17 June 1996
}

Accepted 20 August 1996 diagnostic procedure is important because microfilariae can be cleared from the blood by microfilaricidal drugs or by immunomediated reactions. An infection can also be occult due to either one-sex infections or to prepatent infections (Rawlings 1988).

There are some reports on heartworm occurrence in the State of Rio de Janeiro, however, most of them deal only with stray dogs (Pinto \& Almeida 1935, Pinto \& Luz 1936, Dacorso Filho et al. 1953, Langenegger et al. 1962, Brito et al. 1979). Surveys performed with domiciliary dogs from the city of Rio de Janeiro have shown microfilariae in 27.8\% (Almeida 1981), 34.08\% (Hatschbach et al. 1976) and $7.8 \%$ of the animals (Labarthe et al. 1988). In Niterói city, the prevalence in São Francisco district was said to be $27.8 \%$ (Nascimento \& Wermelinger 1971). When immunoenzymatic test -ELISA- were introduced, $21.34 \%$ of the animals were considered positive in Rio de Janeiro and Niterói cities and its neighborhoods (Labarthe et al. 1990) and Souza (1992) detected the infection in $25.35 \%$ of the animals from a rural area near Rio de Janeiro city.

The present paper presents the description of the occurrence of heartworm in the two largest cities in the State of Rio de Janeiro and its two most popular vacation sites. 


\section{MATERIALS AND METHODS}

The search for D. immitis infection was conducted in dog blood samples at random obtained during two different periods, in the cities of Rio de Janeiro and Niterói and its surroundings as well as in the nearby mountain and beach vacation sites. Most of the animals were brought to the clinics by their owners, although some had their blood taken at home. A record form was completed for each dog, with its identification and history. The autochthony of the cases was not taken under consideration.

In the first period, from April to October 1988, a total of 795 blood samples was obtained from dogs that had been off filaricidal treatment for at least one year and were over 12 months old. In the second period, from January to October 1990, a total of 595 blood samples was obtained from dogs over 12 months old, regardless of filaricidal medication.

Samples were collected in EDTA and kept at $4^{\circ} \mathrm{C}$ until laboratory tests were done. All samples were examined by the modified Knott test to detect circulating microfilariae. In the second phase, samples that showed no microfilariae were also examined by an ELISA test (Cite ${ }^{\hat{a}}$ Semi-Quantô test, IDEXX, Inc, Portland, Maine, USA) to detect antigens of adult heartworms.

To allow for an overview of the distribution of the disease throughout the cities, sections of the study areas were established according to their geographical location, social conditions and urbanizing characteristics. Rio de Janeiro was divided as follows: western section (Bangu, Campo Grande, Santa Cruz and Guaratiba districts), Barra section (Barra da Tijuca, Recreio dos Bandeirantes and São Conrado districts), Jacarepaguá section (Jacarepaguá district), southern section (from Gávea to Leme, including districts from Botafogo to Glória) and eastern section (from Tijuca to Cascadura, including Ilha do Governador district). Niterói and its surroundings were divided as follows: downtown section (from southwestern São Gonçalo city to downtown Niterói), Icaraí section (Icaraí and Santa Rosa districts), São Francisco section (São Francisco, Charitas, Jurujuba and Pendotiba districts) and Oceanic section (Itaipu, Itacoatiara and Piratininga districts). The nearby areas were named eastern shore (from Maricá to Cabo Frio) and mountain resorts (from Petrópolis to Teresópolis) (Fig.).

The statistical analysis was done by homogeneity test, using chi square, with a significance level of $a=5 \%$. The statistics was performed at the Laboratório de Estatística, Universidade Federal Fluminense.
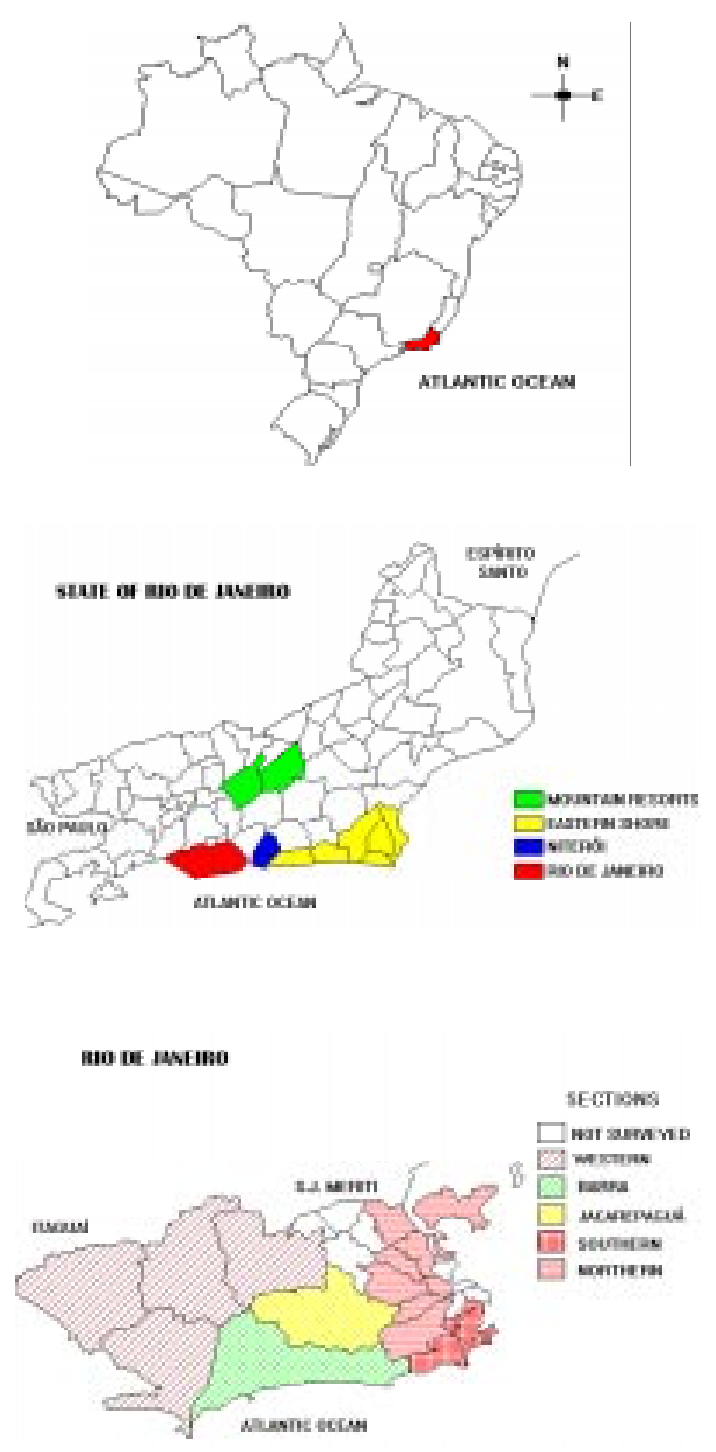

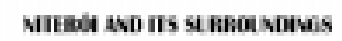

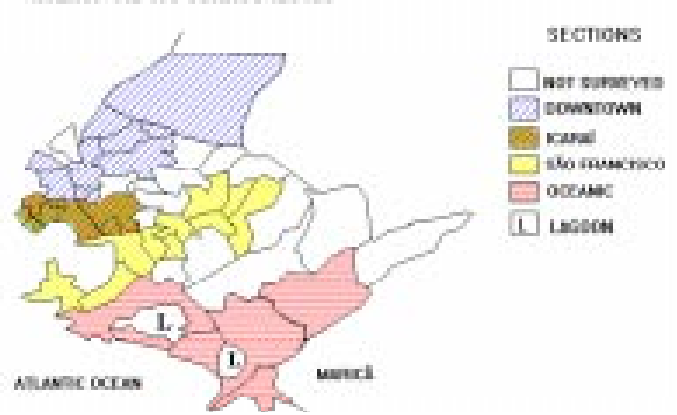

Surveyed areas of the State of Rio de Janeiro $\left(43,305 \mathrm{~km}^{2}\right)$ with details of the Rio de Janeiro $\left(1,171 \mathrm{~km}^{2}\right)$ and Niterói $\left(151 \mathrm{~km}^{2}\right)$ area sections. 


\section{RESULTS}

In the first phase (Table I), where all animals included were off filaricidal medication, the infection rates were $8.61 \%$ for Rio de Janeiro (western section $8.33 \%$, Barra section $12.73 \%$, Jacarepaguá section $15.79 \%$, southern section $5.94 \%$ and eastern section $1.92 \%), 21.76 \%$ for Niterói and its surroundings (downtown section $12.12 \%$, Icaraí section $12.34 \%$, São Francisco section $29 \%$ and Oceanic section $43.40 \%$ ), $33.33 \%$ in the eastern shore and $30.43 \%$ in the mountain resorts. When Niterói and Rio de Janeiro were compared, Niterói and its surroundings showed significantly higher prevalence $(21.76 \%)$ than Rio de Janeiro (8.61\%); and among the Niterói sections, Oceanic (43.40\%) and São Francisco sections (29\%) had the highest prevalences. When compared to downtown and Icaraí sections, the Oceanic section had a significantly higher prevalence value and when compared to the São Francisco section the difference was almost significant $(a=6 \%)$. In Rio de Janeiro, most of the infected dogs were from two sections: Barra (12.73\%) and Jacarepaguá (15.79\%). Both sections had significantly higher prevalence values when compared to the northern section, but only Jacarepaguá was considered to have a higher prevalence value than the southern section. Although the mountain resorts $(30.43 \%)$ and the eastern shore (33.33\%) showed high prevalences, in both places the number of samples was too small to allow for a meaningful comparison.

In the second phase (Table II), where dogs were included regardless of their history concerning filaricidal medication, the infection rates were as follows: Rio de Janeiro, $13.68 \%$ (western section $7.70 \%$, Barra section $30.93 \%$, Jacarepaguá section $11.66 \%$, southern section $2.70 \%$ and northern section $3.61 \%$ ); Niterói and its surroundings, $24.86 \%$ (downtown section $19.44 \%$, Icaraí section $16.67 \%$, São Francisco section $14.63 \%$ and Oceanic section $37.50 \%$ ); eastern shore, $52.46 \%$; and mountain resorts, $20 \%$. When Niterói and its surroundings and Rio de Janeiro were compared, the prevalence value for Niterói $(24.86 \%)$ was significantly higher than that for Rio de Janeiro (13.68\%). Moreover, when comparisons were made among the city sections of Niterói, the prevalence values for the Oceanic (37.50\%) and Barra (30.93\%) sections, were significantly higher than those for the other sections. In this second opportunity, when the prevalence for the eastern shore $(52.46 \%)$ was compared to that for Rio de Janeiro and Niterói and its surroundings, there was a significantly higher number of infected dogs in the eastern shore. In the mountain resorts $(20 \%)$ the sample size was too small to be compared to the other regions.

When the prevalence of occult infections was

\section{TABLE I}

Distribution of canine dirofilariasis in Rio de Janeiro and Niterói and its surrounding areas, according to the detection of microfilariae (MF+) by the modified

Knott test

\begin{tabular}{lccr}
\hline Region & $\begin{array}{c}\text { No. MF+ } \\
\text { Samples }\end{array}$ & $\begin{array}{c}\text { Total } \\
\text { samples }\end{array}$ & $\%$ \\
\hline Rio de Janeiro $^{a}$ & 5 & 60 & 8.33 \\
Western section $^{b}$ & 7 & 55 & 12.73 \\
Barra section $^{c}$ & 9 & 57 & 15.79 \\
Jacarepaguá section $^{d}$ & 6 & 101 & 5.94 \\
Southern section $^{e}$ & 1 & 52 & 1.92 \\
Northern section $^{f}$ & 28 & 325 & 8.61 \\
Sub total $^{\text {Niterói }}{ }^{g}$ & & & \\
Downtown section $^{h}$ & 12 & 99 & 12.12 \\
Icaraí section $^{i}$ & 19 & 154 & 12.34 \\
S. Francisco section $^{j}$ & 29 & 100 & 29.00 \\
Oceanic section $^{k}$ & 34 & 79 & 43.40 \\
Sub total & 94 & 432 & 21.76 \\
Eastern shore $^{l}$ & 5 & 15 & 33.33 \\
\hline Mountain resorts $^{m}$ & 7 & 23 & 30.43 \\
\hline Total $^{\prime}$ & 134 & 795 & 16.85 \\
\hline
\end{tabular}

$a$ : Rio de Janeiro city; $b$ : Bangu, Campo Grande, Santa Cruz and Guaratiba districts; $c$ : Barra da Tijuca, Recreio dos Bandeirantes and São Conrado districts; $d$ : Jacarepaguá district; $e$ : from Gávea to Leme, including districts from Botafogo to Glória; $f$ : from Tijuca to Cascadura, including Ilha do Governador district; $g$ : Niterói city and its surroundings; $h$ : from southwestern São Gonçalo city to downtown Niterói; $i$ : Icaraí and Santa Rosa districts; $j$ : São Francisco, Charitas, Jurujuba and Pendotiba districts; $k$ : Itaipu, Itacoatiara and Piratininga districts; $l$ : from Maricá to Cabo Frio city; $m$ : from Petrópolis to Teresópolis city.

compared, there was no statistically significant difference between the cities of Rio de Janeiro and Niterói. When the Rio de Janeiro sections were compared to each other, the occult infection rate for the Barra section was significantly higher than that for the Jacarepaguá, southern and northern sections. Within the city of Niterói and its surroundings, only the Oceanic section showed a significant higher frequency of occult infections when compared to the Icaraí section. When the eastern shore $(30.95 \%)$ was compared to Rio de Janeiro $(5.65 \%)$ and Niterói and its surroundings $(9.15 \%)$, it had a significantly higher number of occult infected dogs.

When the results of microfilaremic and occult infections for both cities were added, there was a total of 127 infected dogs and 44 of them were amicrofilaremic (Table II). This shows that $34.64 \%$ of the infected dogs had occult infections. 
TABLE II

Canine dirofilariasis in Rio de Janeiro, according to detection of the microfilariae (MF+) by the modified Knott test and by the detection of heartworm antigens by an $\mathrm{ELISA}^{a}$ test

\begin{tabular}{|c|c|c|c|c|c|c|}
\hline \multirow[t]{2}{*}{ Region } & \multicolumn{2}{|c|}{ Knott } & \multicolumn{2}{|c|}{ ELISA } & \multicolumn{2}{|c|}{ Total } \\
\hline & No.+/Total & $\%$ & No.+/Total & $\%$ & No.+combined & $\%$ \\
\hline \multicolumn{7}{|l|}{ Rio de Janeiro $^{b}$} \\
\hline Western section ${ }^{c}$ & $1 / 52$ & 1.92 & $3 / 51$ & 5.88 & $4 / 52$ & 7.70 \\
\hline Barra section $^{d}$ & $18 / 97$ & 18.56 & $12 / 79$ & 15.19 & $30 / 97$ & 30.93 \\
\hline Jacarepaguá section $^{e}$ & $5 / 60$ & 8.33 & $2 / 55$ & 3.64 & $7 / 60$ & 11.66 \\
\hline Southern section $f$ & $1 / 37$ & 2.70 & $0 / 36$ & 0 & $1 / 37$ & 2.70 \\
\hline Northern section ${ }^{g}$ & $3 / 83$ & 3.61 & $0 / 80$ & 0 & $3 / 83$ & 3.61 \\
\hline Sub total & $28 / 329$ & 8.51 & $17 / 301$ & 5.65 & $45 / 329$ & 13.68 \\
\hline \multicolumn{7}{|l|}{ Niterói ${ }^{h}$} \\
\hline Downtown section $^{i}$ & $5 / 36$ & 13.89 & $2 / 31$ & 6.45 & $7 / 36$ & 19.44 \\
\hline Icaraí section $^{j}$ & $5 / 36$ & 13.89 & $1 / 31$ & 3.22 & $6 / 36$ & 16.67 \\
\hline S. Francisco section ${ }^{k}$ & $4 / 41$ & 9.76 & $2 / 37$ & 5.40 & $6 / 41$ & 14.63 \\
\hline Oceanic section $l$ & $18 / 72$ & 25.00 & $9 / 54$ & 16.67 & $27 / 72$ & 37.50 \\
\hline Sub total & $32 / 185$ & 17.30 & $14 / 153$ & 9.15 & $46 / 185$ & 24.86 \\
\hline Eastern shore $^{m}$ & $19 / 61$ & 31.15 & $13 / 42$ & 30.95 & $32 / 61$ & 52.46 \\
\hline Mountain resorts ${ }^{n}$ & $4 / 20$ & 20.00 & $0 / 16$ & 0 & $4 / 20$ & 20.00 \\
\hline Total & $83 / 595$ & 13.95 & $44 / 551$ & 7.98 & $127 / 595$ & 21.34 \\
\hline
\end{tabular}

${ }^{a}$ CITE$^{a}$ Semi-Quantô - Idexx, Inc, Portland, Maine, USA.

$b$ : Rio de Janeiro city; $c$ : Bangu, Campo Grande, Santa Cruz and Guaratiba districts; $d$ : Barra da Tijuca, Recreio dos Bandeirantes and São Conrado districts; $e$ : Jacarepaguá district; $f$ : from Gávea to Leme, including districts from Botafogo to Glória; $g$ : from Tijuca to Cascadura, including Ilha do Governador district; $h$ : Niterói city and its surroundings; $i$ : from southwestern São Gonçalo city to downtown Niterói; $j$ : Icaraí and Santa Rosa districts; $k$ : São Francisco, Charitas, Jurujuba and Pendotiba districts; $l$ : Itaipu, Itacoatiara and Piratininga districts; $m$ : from Maricá to Cabo Frio city; $n$ : Mountain resorts: from Petrópolis to Teresópolis city.

\section{DISCUSSION}

Data presented herein and by previous workers (Langenneger et al. 1962, Souza 1992, Labarthe et al. 1992) suggests that heartworm is widespread in the State of Rio de Janeiro, and this stresses the importance of studying this parasitic disease of dogs living in the surveyed areas. Heartworm is expected to be quite frequent in places where mosquitoes are abundant. In the United States, for example, salt marsh mosquitoes are considered to be efficient vectors of the disease (Sauermann \& Nayar 1983, Otto 1949), due to their high density along the sea shore. In fact, in Rio de Janeiro, most of the workers have conducted heartworm surveys at coastal lowland areas (Dacorso Filho et al. 1953, Langenegger et al. 1962, Labarthe et al. 1988, 1990, Souza 1992) mainly because dirofilariasis is a frequently diagnosed disease in dogs in these areas. Although the present survey included a few animals from the mountain resorts in the State, where salt marsh mosquitoes are absent or scarce, the parasite was found in $30.43 \%$ and $20 \%$ of dogs examined in both phases, respectively; this is frequent enough to be considered a threat to a dog's health. Thus, in the State of Rio de Janeiro, $D$. immitis can be transmitted readily in areas away from the coast as has been shown to occur in other countries (Guerrero 1988, Genchi et al. 1988, Guerrero et al. 1992). These authors have highlighted that when infected dogs from an enzootic area are traveling with their owners to other places, they are good source of infection for local mosquitoes. Thus, under such circunstances, the parasite might well become established in areas previously considered nonenzootic. For this reason, whenever symptoms are present, veterinarians in the State of Rio de Janeiro, should include $D$. immitis in their diagnostic protocol, despite the patients' history of living near the sea.

According to Rawlings et al. (1982) and Grieve et al. (1986), occult infections may occur in up to $30 \%$ of the infected dogs. Although the percentage of occult infections found in the present survey $(34.64 \%)$ is close to the expected frequency, it is quite likely that abusive use of microfilaricidal agents contributed substancially to this high rate. The results of this survey show that in the Barra and Oceanic sections, places where heartworm is 
frequent and the use of microfilaricidal drugs for ectoparasite control is a widespread habit among dog owners, the number of occult infections was higher than in the other sections. Veterinarians should be aware of the risk of misdiagnosing heartworm patients when testing them only for microfilariae, especially in practices where microfilaricidal drugs are used for the control of ectoparasites.

Since dirofilariasis is a zoonosis and is frequently diagnosed in dogs in the State of Rio de Janeiro, human health professionals should seriously consider this parasite among the many possible causes of solitary lesions of the human lung (Levinson et al. 1979). In addition, studies of the vector potential of local mosquitoes and other epidemiological parameters should be conducted to evaluate the possibility of its transmission to man in this State.

\section{ACKNOWLEDGMENTS}

To Prof. Sebastião José de Oliveira and Prof. Ricardo Lourenço-de-Oliveira for their support and for the criticism of the manuscript. To Prof. Vera Maria Colavitti for review of the manuscript. To Prof. Núbia Karla de Oliveira Almeida and Dr Valdenir Bandeira Soares for their accessibility and true help.

\section{REFERENCES}

Almeida GLG 1981. Reavaliação de Filariose Canina no Rio de Janeiro. MSc thesis, Faculdade de Veterinária, Universidade Federal Rural do Rio de Janeiro, Rio de Janeiro, 78 pp.

Brito DB, Lopes AC, Costa CHC 1979. Dirofilariose canina e sua implicação com a saúde do homem. Rev Mun Med Rio de Janeiro 2: 10-13.

Dacorso Filho P, Langenegger J, Dobereiner J 1953. Ocorrência da infestação por Dirofilaria immitis em cães necropsiados na Escola Nacional de Veterinária. Veterinária 7: 22-27.

Genchi C, Traldi G, Di Sacco B, Benedetti MC 1988. Epidemiological aspects of canine heartworm disease in Italy. Atti del $4^{\circ}$ Seminário: Filariosi: 53-64. Italy.

Grieve RB, Glickman LT, Bater AK 1986. Canine Dirofilaria immitis infection in a hyperenzootic area: examination by parasitologic finds at necropsy and by two serodiagnostic methods. Am J Vet Res 47: 392393.

Guerrero J 1988. Aggionornamenti sulla presenza di Dirofilaria immitis in accune regione dell'Europa e del Sud America. Atti del $4^{\circ}$ Seminario: Filariosi: 45-52. Italy.

Guerrero J, Ducos de la Hitte, Genchi C, Rojo F, Gomez-
Bautista M, Varela MC, Labarthe N, Bordin E, Gonzales G, Mancebo O, Patino F, Uribe LF, Samano R 1992. Update on the distribution of Dirofilaria immitis in dogs from Southern Europe and Latin America. In Proceedings of the Heartworm Symposium '92: 31-37, Austin, Texas.

Hatschbach P, Ribeiro S, Ribeiro LAR 1976. Filariose Canina e sua incidência em cães na cidade do Rio de Janeiro. Res XXVIII Reun...Brasília:SBPC: 18.

Labarthe NV, Pereira NR, Soares AM 1988. Prevalência da dirofilariose canina no Rio de Janeiro. An XI Cong Bras Clin Vet Peq An: 38. Fortaleza.

Labarthe NV, Pereira NR, Soares AM, Bordin E, Rotta A, Guerrero J 1990. Dirofilariose canina no Estado do Rio de Janeiro: prevalência das formas oculta e microfilarêmica. An XII Cong Bras Clin Vet Peq An: 16. Gramado.

Labarthe NV, Almosny NR, Soares AM, Souza-Silva LC 1992. Update on the distribution of Dirofilaria immitis in the State of Rio de Janeiro, Brazil. Proceedings of the XVII WSAVA World Congress: 291-293. Italy.

Langenegger J, Almeida GLG, Langenegger A 1962. Ocorrência de microfilárias em cães do Rio de Janeiro. Veterinária 15: 59-70.

Leidy J 1856. A synopsis of entozoa and some of their ectocongeners observed by the author. Proc Acad Natl Sci 8: 42.

Levinson ED, Ziter FMH, Westcott JL 1979. Pulmonary lesions due to Dirofilaria immitis (dog heartworm). Radiology 131: 305-307.

Nascimento MD, Wermelinger LM 1971. Incidência de microfilárias em cães em Niterói (bairro de São Francisco). Rev Med Vet 7: 138-143.

OMS-Organización Mundial de la Salud 1979. Zoonosis parasitarias. Informe Técnico 637: 105-106.

Otto GF 1949. Heartworm in dogs. North Am Vet 30: 181-189.

Pinto C, Almeida JL 1935. Sinopse dos helmintos dos animais domésticos do Brasil. O Campo 6: 54-63.

Pinto C, Luz A 1936. Dirofilaria immitis na vesícula biliar de Canis familiaris. O Campo 7: 36-37.

Rawlings CA 1988. La filariosi oculta. Atti del $4^{\circ}$ Seminario: Filariosi: 96-102. Italy.

Rawlings CA, Dave DL, McCall JW 1982. Four types of occult Dirofilaria immitis infection in dogs. JAVMA 180: 1323-1326.

Sauerman Jr DM, Nayar JK 1983. A survey for natural potential vectors of Dirofilaria immitis in Vero Beach, Florida. Mosq News 43: 222-225.

Souza SSHVC 1992. Diagnóstico da dirofilariose através da detecção de antígenos circulantes em cães no Estado do Rio de Janeiro. MSc thesis, Faculdade de Veterinária, Universidade Federal Rural do Rio de Janeiro, Rio de Janeiro, 87 pp. 
